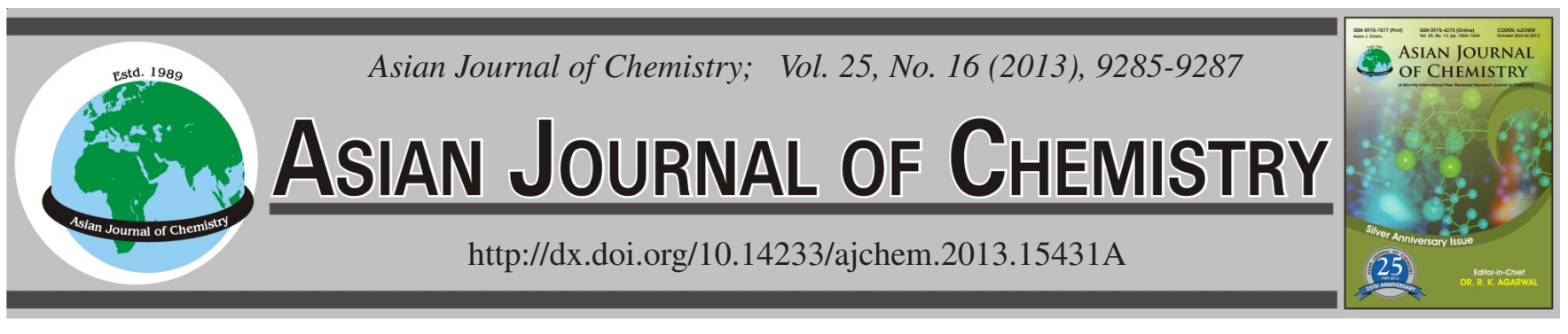

\title{
Oil Content, Saturated and Unsaturated Fatty Acids of Some Linseed (Linum usitatissimum L.) Genotypes
}

\author{
Züleyha Endes ${ }^{1}$, Fatih ER $^{1}$, Mehmet Musa ÖZcan ${ }^{2, *}$ and Fahad Al Juhaimi ${ }^{3}$
}

${ }^{1}$ Cumra Vocational High School, Selcuk University, 42500 Konya, Turkey

${ }^{2}$ Department of Food Engineering, Faculty of Agriculture, Selcuk University, Konya, Turkey

${ }^{3}$ Department of Food Science \& Nutrition, College of Food and Agricultural Sciences, King Saud University, Riyadh, Saudi Arabia

*Corresponding author: Fax: +90 332 2410108; Tel: +90 332 2232933; E-mail: mozcan@ selcuk.edu.tr

(Received: 6 March 2013;

Accepted: 20 September 2013)

AJC-14162

The main fatty acid components of genotypes identified by gas chromatography were linolenic acid (48.3\%), linoleic acid (11.5\%), oleic acid (30\%), palmitic acid (5.8\%), stearic acid (6.7\%), palmitoleic acid $(0.41 \%)$. According to the results, oil rates of genotypes were in the range of $24.5-28.8$ and $12.5 \%$ of these ratio was saturated, $90 \%$ was unsaturated fatty acids. It was determined that microbial fertilizer had importance on stearic $(\mathrm{p}<0.01)$ and linolenic $(\mathrm{p}<0.05)$ fatty acids statistically.

Key Words: Linseed, Microbial fertilizer, Chemical fertilizer, Gas chromatography, Saturated and unsaturated fatty acids.

\section{INTRODUCTION}

Linseed oil is derived from the seeds of flaxseed (Linum usitatissimum L., a plant widely cultivated in Europe for fiber or oil for industrial use ${ }^{1}$. Linseed with its high oil content (30$45 \%$ ) can be used in edible and non-edible industrial oil production. The quality of oil depends upon its fatty acid composition which ultimately determines its utilization in industry. Due to the high iodine number, it is used in making varnishes, linoleum, printing ink, soap, leather, mac, resin manufacturing, paint and coatings industry ${ }^{2}$.

Fertilizer is used to promote the development and increase the yield and quality. Chemical fertilizers are widely used in modern agriculture as the basic lant nutrients. However, excessive use of the fertilizers can be dangerous for the environment ${ }^{3}$. Some new techniques are being developed to eliminate the negative effect of the chemicals on the environment and to reduce the use of chemical without decreasing the yield and quality. One of the techniques developed is microbial fertilizing through bacteria ${ }^{4}$. These bacteria promote the efficient use and usefulness of the nutrients and they are effective on growth and development of the plant $t^{5,6}$.

With this study, saturated and unsaturated fatty acids were determined on the linseed genotypes grown in different fertilizer (microbial-chemical). The demand for this plant will increase by determining the differences between the applications and the suitable varieties in terms of yield and quality and through developing these varieties. Additionally, if the required result is taken from the microbial fertilizer application, environmental pollution can be prevented by minimizing the use of chemical fertilizers that pose a great threat to the health of living creature.

\section{EXPERIMENTAL}

In the study, domestic and foreign five oil linseed genotypes (Linum usitatissimum L.) which are obtained from different sources, were used as material. Antares, Atalanta, Avangard and Maroc SM are German-originated oil linseed genotypes. One of the indigenous materials, obtained from Ankara University Faculty of Agriculture, is Sari-85. It is the only registered linseed variety. Flax seeds obtained from the various sources, were inoculated with the bacterium Bacillus pumilis 189. Bacillus pumilis 189 was isolated from the rhizosphere of the wheat ( Triticum aestivum L. ) grown in Konya region ${ }^{7}$.

The research was conducted on the experimental area of the Selcuk University Cumra Vocational High School (32:31E and $37: 52 \mathrm{~N}$ at an altitude of $1016 \mathrm{~m}$ ) in the irrigation conditions in 2010. The experiment was established according to the "Split Plots on Randomized Complete Block Experimental Design" with three replications. Fertilizers (microbialchemical) and genotypes were constituted the main plots and sub-plots, respectively. Planting was made by hand with 20 $\mathrm{cm}$ row-spacing and 2-3 cm depth. Sub-plots were arranged in 6 rows with the size of $1.0 \mathrm{~m} \times 2.0 \mathrm{~m}=2.0 \mathrm{~m}^{2}$. Sowing was made 5 May 2010. In the study, fertilizer application was not made on the plots that had microbial fertilizer application (Bacillus pumilis 189) but chemical fertilizer application was 
made (DAP fertilizer ) on the other plots. $100 \mathrm{~kg}$ nitrogen were applied for an hectare and $110 \mathrm{~kg} \mathrm{ha}^{-1}$ phosphorus $\left(\mathrm{P}_{2} \mathrm{O}_{5}\right)$ was applied during sowing. Harvesting was made by hand on 10 August 2010. The seeds from these genotypes were used for analysis.

The sample ( $5 \mathrm{~g}$ ) was taken from the extracted and crushed seeds and oil analysis was made. Crude oil ratios were determined by using the solvent method with petroleum ether extraction. The sequence was as follows: grinding-Soxhletevaporation ${ }^{8}$.

Determination of fatty acids: Triglycerides available in the chemical structure of oil were determined by gas chromatography device ${ }^{9}$. The working conditions of gas chromatography were as follows: Instrument: Shimadzu GC-14B, Constant phase: $10 \%$ diethylene glycol succinate (DEGS) Support matter: Chromosorb W(AW-DMCS) (60-80 mesh), Detector: FID (flame ionization detector), temperatures: column: $180{ }^{\circ} \mathrm{C}$, injector: $200^{\circ} \mathrm{C}$, detector: $200{ }^{\circ} \mathrm{C}$, flow rates: carrier gas $\left(\mathrm{N}_{2}\right): 30 \mathrm{~mL} / \mathrm{min}$, Burnt gas $\left(\mathrm{H}_{2}\right): 28 \mathrm{~mL} / \mathrm{min}$, dry gas $\left(\mathrm{O}_{2}\right): 220 \mathrm{~mL} / \mathrm{min}$, Printer: Chromatopac CR 6A (Shimadzu), injection amount: $0.5 \mu \mathrm{L}$.

Statistical analyses: The results of the research were analyzed by analysis of variance in MSTAT statistical program according to "split plots on randomized complete block" with three replicants.

\section{RESULTS AND DISCUSSION}

Oil ratios, saturated and unsaurated fatty acid contents belonging to the genotypes are given in Table- 1 . The percentage of oil content ranged from $24.5 \%$ (Antares) to 28.8 (Avangard and Sari-85). Tunçtürk ${ }^{10}$ obtained smilar results in different Linum varieties in respect of the oil content 28.9$35.2 \%$. The percentage of palmitic acid ranged from 5.6 (Atalanta, Maroc SM, Sari-85) to 6.3 (Avangard); stearic acid ranged from 6.0 (Avangard) to 7.5 (Antares); palmitoleic acid ranged from 0.25 (Avangard) to 0.77 (Antares); oleic acid ranged from 24.4 (Sari-85) to 35.1 (Antares); linoleic acid ranged from 10.0 (Sari-85) to 12.4 (Antares); linolenic acid ranged from 43.8 (Atalanta) to 55.3 (Sari-85). Among the fatty acids linolenic acid was found to be major acid in all the genotypes. The greatest variability was found in the linolenic acid fallowed by the oleic acid. Sekhon et al. ${ }^{11}$ obtained smilar results in different Linum varieties in respect of the linolenic acid (40.9-56.4\%) and oleic acid (14.7-39.0\%), McGregor and Carson $^{12}$ also found variability within Linum species in the oil composition (46.2-54.6\%) and the oleic acid (24.4$31.8 \%$ ) which is in close agreement with the present finding.
The main fatty acid components of genotypes identified by gas chromatography were linolenic acid $(48.3 \%)$, linoleic acid $(11.5 \%)$, oleic acid (30\%), palmitic acid (5.8\%), stearic acid $(6.7 \%)$, palmitoleic acid $(0.41 \%)$ (Fig. 1). Endes et al. ${ }^{13}$ obtained similar results in Linum genotypes in respect of the linolenic acid (51\%), linoleic acid (13\%), oleic acid (22\%), palmitic acid $(6 \%)$, stearic acid $(7 \%)$, palmitoleic acid (1\%). According to the mean results, oil rates of genotypes were in the range of 24.5-28.8\% (Antares and Sari-85) and $12.5 \%$ of these ratio was saturated, $90 \%$ was unsaturated fatty acids. Bayrak et al. ${ }^{14}$ obtained similar results in Linum genotypes in respect of the saturated and unsaturated fatty acid contents varied from 7.97 to $12.30 \%$ and 84.90 to $92.03 \%$. Generally, linseed oil contains approximately $9-11 \%$ saturated (5-6\% palmitic acid and 4$5 \%$ stearic acid) and 75-90\% unsaturated fatty acids (50$55 \%$ linolenic acid, $15-20 \%$ oleic acid $)^{15}$.

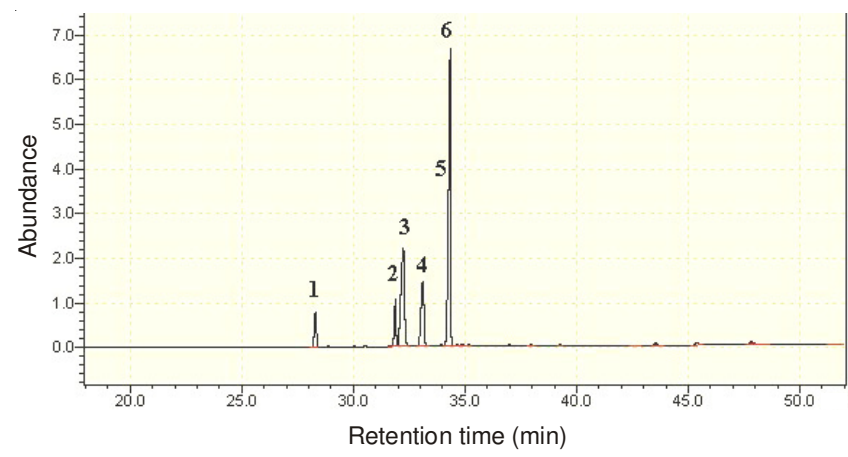

Fig. 1. GC-chromatogram of linseed fatty acids (1) palmitic acid, (2) palmitoleic acid, (3) stearic acid, (4) oleic acid, (5) linoleic acid, (6) linolenic acid

The highest values among the polyunsaturated fatty acids belong to the linolenic fatty acids and the highest values among the monounsaturated fatty acids belong to the oleic fatty acids. Vaisey-Genser and Morris ${ }^{16}$ found that oil rates in flax seeds were in the range of 35,40 and $9 \%$ of this ratio was saturated, $18 \%$ was monounsaturated and $73 \%$ was polyunsaturated (linolenic acid $57 \%$, linoleic acid $16 \%$ ) fatty acids.

Oil content, saturated and unsaturated fatty acid values in different fertilizer aplications (microbial-chemical fertilizer) were given in Table-2. Microbial fertilization has been effective on fatty acids statistically at the level of $p<0.01$ and $p<0.05$ but chemical fertilization has no statistically importance on fatty acids. The highest oil content rate was obtained from chemical fertilizer $(28.4 \%)$, the lowest oil content rate was obtained from microbial fertilizer (26.4\%). Palmitic acid (5.8\%)

TABLE-1

OIL CONTENT, SATURATED AND UNSATURATED FATTY ACIDS IN LINSEED GENOTYPES

\begin{tabular}{|c|c|c|c|c|c|c|c|c|}
\hline \multirow{2}{*}{$\begin{array}{c}\text { Genotype } \\
\text { No. }\end{array}$} & \multirow[b]{2}{*}{ Genotypes } & \multirow{2}{*}{$\begin{array}{l}\text { Oil contents } \\
(\%)\end{array}$} & \multicolumn{2}{|c|}{ Saturated fatty acids $(\%)$} & \multicolumn{4}{|c|}{ Unsaturated fatty acids (\%) } \\
\hline & & & $\begin{array}{l}\text { Palmitic } \\
\text { C: } 16\end{array}$ & $\begin{array}{c}\text { Stearic } \\
\mathrm{C}: 18\end{array}$ & $\begin{array}{c}\text { Palmitoleic } \\
\text { C: } 16: 1\end{array}$ & $\begin{array}{c}\text { Oleic } \\
\text { C:18:1 }\end{array}$ & $\begin{array}{c}\text { Linoleic } \\
\text { C: } 18: 2\end{array}$ & $\begin{array}{c}\text { Linolenic } \\
\text { C:18:3 }\end{array}$ \\
\hline 1 & Antares & 24.5 & 5.9 & 7.5 & 0.77 & 35.1 & 12.4 & 43.9 \\
\hline 2 & Atalanta & 26.7 & 5.6 & 6.7 & 0.29 & 32.8 & 11.9 & 43.8 \\
\hline 3 & Avangard & 28.8 & 6.3 & 6.0 & 0.25 & 27.1 & 11.3 & 51.5 \\
\hline 4 & Maroc SM & 28.5 & 5.6 & 6.6 & 0.45 & 32.2 & 11.9 & 47.5 \\
\hline \multirow[t]{2}{*}{5} & Sari- 85 & 28.8 & 5.6 & 6.9 & 0.29 & 24.4 & 10.0 & 55.3 \\
\hline & Mean & 27.4 & 5.8 & 6.7 & 0.41 & 30.3 & 11.5 & 48.4 \\
\hline
\end{tabular}




\begin{tabular}{|c|c|c|c|c|c|c|c|}
\hline \multicolumn{8}{|c|}{$\begin{array}{c}\text { TABLE-2 } \\
\text { OIL CONTENT, SATURATED AND UNSATURATED FATTY ACIDS IN DIFFERENT FERTILIZER APPLICATIONS }\end{array}$} \\
\hline \multirow[b]{2}{*}{ Fertilizers } & \multirow{2}{*}{$\begin{array}{l}\text { Oil contents } \\
\quad(\%)\end{array}$} & \multicolumn{2}{|c|}{ Saturated fatty acids (\%) } & \multicolumn{4}{|c|}{ Unsaturated fatty acids (\%) } \\
\hline & & $\begin{array}{l}\text { Palmitic } \\
\text { C: } 16\end{array}$ & $\begin{array}{l}\text { Stearic } \\
\text { C: } 18\end{array}$ & $\begin{array}{l}\text { Palmitoleic } \\
\text { C:16:1 }\end{array}$ & $\begin{array}{l}\text { Oleic } \\
\text { C: } 18: 1\end{array}$ & $\begin{array}{l}\text { Linoleic } \\
\text { C: } 18: 2\end{array}$ & $\begin{array}{l}\text { Linolenic } \\
\text { C: } 18: 3\end{array}$ \\
\hline Microbial fertilizer & 26.4 & 5.8 & $7.3 \mathrm{a}^{* *}$ & 0.28 & 30.3 & 10.8 & $50.5 \mathrm{a}^{*}$ \\
\hline Chemical fertilizer & 28.4 & 5.8 & $6.1 \mathrm{~b}$ & 0.54 & 30.3 & 12.2 & $46.2 \mathrm{~b}$ \\
\hline Mean & 27.4 & 5.8 & 6.7 & 0.41 & 30.3 & 11.5 & 48.4 \\
\hline
\end{tabular}

and oleic acid $(30.3 \%)$ rates did not change by both of the fertilizations. The highest stearic acid rate was obtained from microbial fertilizer $(7.3 \%)$, the lowest stearic acid rate was obtained from chemical fertilizer $(6.1 \%)$. The highest palmitoleic acid ratio was obtained from chemical fertilizer $(0.54 \%)$, the lowest palmitoleic acid rate was obtained from microbial fertilizer $(0.28 \%)$. The highest linoleic acid ratio was obtained from chemical fertilizer $(12.2 \%)$, the lowest linoleic acid rate was obtained from microbial fertilizer $(10.8 \%)$. The highest linolenic acid ratio was obtained from microbial fertilizer $(50.5 \%)$, the lowest linolenic acid rate was obtained from chemical fertilizer $(46.2 \%)$. The amount of oil and fatty acids composition of the oil crops are variable and they are under the influence of the various genetic, physiological, ecological and cultural factors. In many oil plants, fatty acids are sensitive to the various cultural factors especially to the fertilizer.

\section{Conclusion}

The research results reveal that microbial and chemical fertilizers had a strong effect on the characters of the varieties. Antares was composed of genotypes striking with high oleic acid content that was important in terms of the biological nutritional value. Linoleic acid is important for prevention of bad cholesterol and cardiovascular health. For this purpose, Antares is seen as the suitable genotype for human health. Linolenic acid of the genotype is requested to be high for paint and varnish industry. In present study Sari-85 which has high amount of linolenic acid, can be proposed for the industrial purposes. To be able to use an oil as an edible oil, it must have low linolenic oil acid. In our research, Atalanta and Antares with low linolenic acid content may be able to be used for cooking through breeding.

\section{ACKNOWLEDGEMENTS}

This work was financed by the Selcuk University Scientific Research Project, Konya, Turkey (Project No. 10401070).

\section{REFERENCES}

1. K. Prasad, Atherosclerosis, 132, 69 (1997).

2. W. Schuster, Ölflangen in Europa, DLG-Verlglas-Gmbh, Eschborner lands-trabe, Germany. Vol. 122, pp. 102-107 (1992).

3. D. Malakoff, Science, 281, 190 (1998).

4. A. Khalid, M. Arshad, B. Shaharoona and T. Mahmood, Plant Growth Promoting Rhizobacteria and Sustainable Agriculture. Microbial Strategies for Crop Improvement, Springer Dordrecht, p. 134-137 (2009).

5. B.R. Glick, B. Todorovic, J. Czarny, Z. Cheng, J. Duan and B. McConkey, Crit. Rev. Plant Sci., 26, 227 (2007).

6. P.A.H.M. Bakker, J.M. Raaijmakers, G.V. Bloemberg, M. Hofte, P. Lemanceau and M. Cooke, Eur. J. Plant Pathol., 119, 241 (2007).

7. M. Ögüt, F. Er and G. Neumann, Plant Soil, 339, 285 (2011).

8. A. Dogan and F. Basoglu, Yemeklik bitkisel yag kimyasi ve teknolojisi uygulama klavuzu, Ankara University Agriculture Fac. Turkey, p. 951 (1985).

9. E. Simsek, Master Thesis, The Effect of Different Roasting Techniques on Physical and Chemical Propertes of Some Oil-Bearing Seeds, Selcuk University Graduate School of Natural and Applied Sciences Department of Food Engineering, Konya, Turkey, p. 67 (2009) (in Turkish).

10. M. Tunctürk, Tarim Bil. Derg., 13, 365 (2007).

11. K.S. Sekhon, K.S. Gill, K.L. Ahuja and R.S. Sandhu, Oleaginaux, 28, 525 (1973).

12. W.G. McGregor and R.B. Carson, Can. J. Plant Sci., 41, 716 (1961).

13. Z. Endes, F. Akinerdem and M.M. Özcan, Asian J. Chem., 24, 2221 (2012).

14. A. Bayrak, M. Kiralan, A. Ipek, N. Arslan, B. Cosge and K.M. Khawar, Biotechnol. Biotechnol. Equip., 24, 1836 (2010).

15. G. Robbelen, R.K. Downey and A. Ashi, Oil Crops of the World, McGraw-Hill Inc, New York (1989).

16. M. Vaisey-Genser and D.H. Morris, Flaxseed (Health, Nutrition and Functionality), Flax Council of Canada, Winnipeg, Manitoba, Canada (1997). 